\title{
Research Performance of Higher Education Institutions
}

\author{
BIENVENIDO L. GREGORIO \\ drblgregory@yahoo.com \\ Universidad de Zamboanga
}

Date Submitted: January 11, 2007

Final Revision Accepted: May 3, 2007

\begin{abstract}
Higher education institutions in Zamboanga Peninsula continue to have low participation in research among their members of the faculty, which in turn affects the research outputs of Research Centers (RCs). The study assessed the research performance and outputs of teachers and RCs among HEIs in Zamboanga City. Public and private schools have similar research performances in terms of the number of researches performed by each teacher-researcher; and with the number of researchers per research. In both cases however, HEIs with university status performed better than the colleges in research. Most of the researches can be classified as institutional, descriptive in type, mostly published in in-house journals and not peer reviewed. Utilization of research outputs is limited much as most researches are school-funded. CHEDRO and ZRCs lacked coordination and initiative to take the lead in building the culture of research among the HEIs in the city. Access to foreign funding, international refereed journals and genuine utilization of research outputs are for the moment marginal. Concluding, the HEIs in Zamboanga City have relatively low research outputs even more among the colleges.
\end{abstract}

Key words - Research performance, research centers, peer review

\section{INTRODUCTION}

Research is one of the tri-fold functions of every higher education institution. Like instruction and community services, research holds a significant role in the furtherance 
of the teaching-learning process. Despite this significance, research has not been well understood or accepted as a component of higher instruction by some members of the academe. Factors like teachers' teaching loads and lack of administrative support are common reasons among teachers in teaching-based higher education institutions not to get involved in research works. Empirical research has not yet been widely considered as part and parcel of the teaching function of teachers in higher education institutions.

The Commission on Higher Education made research a criterion in the grant of university status as well as in the conferment of de-regulated and autonomous status. CHED Memorandum Order Number 8, series of 2000, was issued to further the role of research among higher education institutions by creating Zonal Research Centers or ZRCs in the country and providing subsidy to Zonal Centers in the pursuit of research undertaking following the adoption of the National Higher Education Research Agenda or NHERA. Despite this policy, only twelve (12) higher education institutions qualified as Zonal Research Centers.

For Region IX, Mindanao State University-Iligan Institute of Technology is designated as Zonal Research Center despite its being outside the political subdivision of the Zamboanga Peninsula and the presence of three (3) universities in Zamboanga City. Higher Education Institutions in Zamboanga City have yet to begin establishing their Research Centers (RCs) or Research Offices (ROs) to institutionalize research in their priority programs. To do this, each institution has to harness the best talents among its members of the academe and instill capability building to sow the seeds for the Culture of Research, a task that requires investment in human resource. Evaluation of research outputs has been crucially crafted in such a way as to make research productivity more relevant and useful. Research outputs must impact society by the generation of more concrete and empirical explanations to knowledge formation or theories that have practical applications. Because research capability among teachers and financial resources are scarce commodities, only few higher education institutions in the country could be acclaimed as research-based institutions.

At present, still many of the higher education institutions are teaching-based although efforts have been expended to cope with the requirements of CHED on research especially the provision on research in the IQuAME. For this reason, there is a need to take an empirical look at the higher education institutions' status in terms of research performance of their research centers and faculty.

\section{FRAMEWORK}

The study adopts the following theories explained below in an effort to help in the contextualization of the research framework and variables used in the study.

Capability and Performance. In terms of capability and performance as variables of this study, the research adopts the Skinner's Operant Conditioning Theory of 
Learning. Performance of researchers is the result of processed inputs that lead them to generate certain research outputs. Therefore, it is very significant that capability building must be an essential phase of any research effort. Skinner (2007) developed his theory in the 1930s in an attempt to analyze how animals and humans alike undergo the process of learning. Focus was, however, made on the learned behavior rather than on cognitive learning that makes his theory a behavioral approach. The theory on learning espoused by Skinner (2007) equally applies in research capability building and performance much in the same way as in any learning process for which the theory was first developed. The theory is best explained following the five (5) basic Principles of Operant Conditioning, namely Reinforcement; Punishment; Shaping; Extinction; and Generalization-Discrimination.

Accordingly, learning starts with reinforcement. By reinforcement is meant that learners are introduced to a learning situation by way of experience. Experiences must be as pleasant as possible so as to strengthen or sustain the performance of similar behavior. Huberman (1995), explaining reinforcement as used by Skinner and Thorndike, shows two (2) types of reinforcement - Positive Reinforcement and Negative Reinforcement. It is positive when a pleasant stimulus is presented every time the expected behavior is performed. It is negative when certain behavior is discouraged. Turnbull (1992) explains, however, that there are two (2) components of Negative Reinforcement. The escape component of Negative Reinforcement suggests that certain behavior is performed to escape experiencing unpleasant stimulus while the avoidance or omission component of Negative Reinforcement suggests that certain behavior is performed to avoid experiencing unpleasant consequences. Applied in the area of research performance, the theory explains that the reward system in the institutional policy may be an agent of reinforcement by which researchers are motivated to undertake research works. It is, however, more of a positive rather than a negative reinforcement. As in theory, motivation in practice is important to lead people to undertake research. This comes in forms of additional monetary incentives and increase in academic rank of teachers in college. But as a prelude to actual performance, teacher-researchers must first have enough grounding to undertake research works whether through formal studies or training.

Fuhrman (1992) emphasizes that punishment performs learning role. Punishment as agent of learning means that a behavior is weakened by delivering an unpleasant stimulus or consequence as a result of the continuous performance of the discouraged behavior. It comes in the same mode as reinforcement. It is a Positive Punishment when behavior is reduced through the instigation of unpleasant stimulus like inflicting pain for a wrong act done. It is a Negative Punishment when the behavior is reduced through removing the pleasant stimulus as a result of the continuous behavior like taking out a privilege previously granted. This principle in Operant conditioning is 
neither particularly relevant in research capability building nor in actual research performance because non-performance in research is not a punishable omission.

Shaping as a principle in Operant Conditioning means introducing the simplest things where humans have never encountered before. From the simplest idea, learners are introduced to the more complex of things until they get mastery of the learned behavior. This kind of principle is used to teach children in the preschool level to prepare them for higher school tasks. When applied to research, this is a very good preparation in capability building although since researchers are professionals, they are presumed to have prior knowledge of research even though they may not have the experience in performing it extensively.

Extinction as another principle in Operant Conditioning means the reduction of reinforcement causing the decline in the learned behavior. Huberman (1992) explains that learned behavior is not permanent. As such, its performance is diminished over time with the reduction of the required reinforcement that first led to that behavior. Forgetting replaces memory of the thing, reduces behavior. As in any learning process, constant and regular capability building in research is essential until mastery is achieved. Research is an applied science that means theories learned must be applied in actual research performance; hence, constant practice is essential to avoid the loss of mastery needed in actual performance. Re-training is an important strategy in this case.

Generalization as another principle in Operant Conditioning means that a behavior learned in one situation is applied to other similar situation whereas Discrimination is its exact opposite. Given prior knowledge in research work, teacher-researchers will find it easy to acquire momentum to undertake research when reinforced with proper motivation and preparation. This behavioral approach in learning is found to be relevant in research capability building and performance as a theory because research is performance-oriented. This means that learned ideas about research are simply tools to facilitate actual research undertaking. Repeated research undertaking is significant to research mastery. The lure to undertake more research works only stems from the person's constant attachment to doing research work. No amount of research knowledge learned will lead to a heightened performance without the actual experience of doing research.

Output. In terms of research output as a variable, this study adopts the concept espoused by Cross (2000), which states that research findings and practice are interrelated and inseparable. Unless research outputs are translated to operational policy for development, research efforts are meaningless. Cross (2000) explains that research findings that are not shared with practitioners in ways that foster application are ineffective. Educational institution must keep itself abreast with the latest knowhow in teaching and learning that is abundant in the environment. More than the 
packaging of the findings, the engagement of the researcher in disseminating findings has an impact on whether those findings are acknowledged and considered by potential users (Huberman, 1992). Research findings must be translated to policy for eventual implementation whenever the situation calls for development change. This presupposes that researchers (teachers) must have a link with the end-users or stakeholders. Huberman (1995) claims that researchers and their research benefit from engaging in dialogue, over time, with practitioners who have experienced the phenomena in which the researcher is interested and that which fosters him with challenges. This will bring about utilization of research findings.

In this framework, it is significant that teacher-researchers must have good research working knowledge, experience in research work, and the required training that supports research performance. These factors must translate into actual engagement in research and actual collaboration with stakeholders and practitioners for research to be meaningful and valuable. Turnbull (1992) says that teachers and policymakers do learn from research but not in a linear way. Teachers scan the environment for new ways of thinking and are most apt to apply those ways if they have the chance to "work on increasing their professional competence in settings of collaboration and mutual support". Collaboration must be close to home. Teachers seek approval from each other, particularly from colleagues they consider more experienced. This is essential because teachers perform not only teaching function but likewise research function. These two functions complement for a relevant higher education instruction. The degree of working knowledge in research affects the significant involvement of teachers in the undertaking. Experience in research undertaking underscores the quality output of research and its eventual utilization. Research training is geared towards improving techniques and skills in research. These fundamental factors cannot be dispensed with in the attempt to perform quality researches.

In order for research outputs to reach its intended beneficiaries, research utilization is indispensable. In fact, utilization is the first phase upon which stakeholders shall have the baseline to comprehend, analyze, and actually use the output in its desired mode. According to Fuhrman (1992), providing research information to practitioners in an accessible form is only the beginning: providing venues for exploration, reflection, implementation, and more reflection are necessary for educational change and improvement to occur. It is in this way that research output becomes valuable. In an educational system where changes are ensued through experimentation and with deliberate care, research basically becomes a tool to instigate the needed academic change that is founded on empirical observation. In a constructivist approach to research utilization, the practitioner constructs meaning out of the research, taking into account the context of her setting and her prior knowledge (Fuhrman, 1992). Policy makers must in fact start listening to the classroom situations as the focus area 
of development in education. Integration of policy into the curriculum without valid referral from the classroom level is definitely misleading and could not guarantee the occurrence of development change.

In its entirety, researches cannot reach their intended beneficiaries without adequate grounding in terms of institutional support and linkages. Inevitably, any research undertaking requires financial support. This support enables researchers to bring research to its intended beneficiaries. However, the lack of this support jeopardizes any research undertaking no matter how crucial and beneficial the effort would be. The way each institution looks at support to research depends on its thrust (including financial capability and willingness) and the academic community undertakes research in ways it appreciates this support. In some instances, schools undertake research only to pay lip service to satisfy minimum government regulations.

The true essence of research is utility that serves as the means through which development policy may be instituted for change. It is this change that serves as the end purpose of every research effort. The school system as a whole must understand this research-utility relation. Huberman (1995) believes that teachers seek out truth and utility. They look for research findings that fit with their experience, and, better still, are vouched for by trusted colleagues. On the utility side, teachers look for research findings that can help them improve their current practice. If they can easily implement suggestions and then quickly see results with their current students, they are more likely to continue to implement the new approach or idea.

According to Garner, Bingman, Comings, Rowe, \& Smith cited by Fetalver (2003), policymakers look for research that demonstrates high technical quality and findings that fit with their understanding of the issue. At the same time, the research must provide explicit policy direction. Suitability and appropriateness to the situation matter a lot in the utilization of research output. Research results must bring something out of the ordinary. In fact, according to Weiss (1999), if the findings challenge convention, all the better. A study that says "more of the same" is not as exciting to policymakers as one that forges a new path. "Keep doing what you're doing" does not provide a framework for legislation.

Higher education institutions or HEIs are classified into public and private school types and further classified into college and university according to status. All respondent schools have certain number of research-performing teachers and functional research centers that differ from each other in research performance and research output aspects. Research performance is measured in three (3) ways, namely: the number of researches undertaken by each teacher-researcher, the number of researchers per research, and the average number of research-performing teachers in the five year period. A school may have more completed researches than the other but with fewer researchers or more researchers with fewer completed researches. 
Research outputs specifically relate to completed research works of each of the school respondents, which are operationally classified into nature of research, type of research, type of funding source, type of publication, and extent of research utilization. The nature of research outputs may be classified into institutional, social, and grant. The type of research output may be classified into descriptive, historical, and experimental research. The descriptive type is further classified into quantitative research, qualitative research, and mixed. Funding source is categorized into self-funded research, schoolfunded research, outsourced research, and other types while type of publication is categorized into school journal (in-house), refereed journal (peer reviewed), and other types. Outputs are also classified in terms of research utilization, either school-utilized or agency-utilized.

All performances and outputs are operationally affected by two important factors: namely: obstacles faced by each school and the current research programs in place. Obstacles are varied but may be classified into three broad areas: research and publication, research dissemination, and research linkage and networking. All other obstacles may fall in one or the other of these categories. Present research programs largely depend on the existing institutional policies, plans, and programs designed to enhance, improve, and develop current research climate in the institution. In view of all these variables, the research findings of this study are considered significant in the development of policies by each of the respondent schools and concerned government agency like the Commission on Higher Education or CHED in an effort to make higher education institutions research-productive and responsive.

\section{OBJECTIVES OF THE STUDY}

The study had the following objectives: (1) to determine the research performance of the faculty; (2) to compare research performance of schools; (3) to describe the research centers' outputs; (4) to characterize the established mechanisms and research agenda across all schools; and (5) to identify the current obstacles experienced by researchers.

\section{METHODOLOGY}

The study used the evaluative-descriptive design utilizing both quantitative and qualitative research types. It is evaluative-descriptive because the data gathering made an evaluation of the variables used in the study with particular reference to official documents of the Research Centers (RCs) of each respondent HEI. This evaluation took into consideration recent records covering a five-year period. The study is 
partly quantitative because it partly relied on quantitative data elicited through questionnaires analyzed by the use of descriptive statistical tools. The study is also partly qualitative because it used some techniques, which are inherently qualitative to answer some problems of the research, which are better done in narrative rather than in statistical form. The use of these two methods was significant as one data source reinforced the other, making research findings more comprehensive and in-depth. The respondents or sources of the study included the following: (a.) Persons: Directors of Research Centers or Deans of Colleges Concerned, Faculty of the Different Colleges; (b.) Documents:Research Output Records, Publication Media, Funding Source DocumentsMemorandum of Agreements, Research Utilization Records, Institutional Research Agenda, and Manual of Regulations.

At present, there are a total of 63 higher education institutions throughout Region IX. Of this number, $79.37 \%$ or 50 are private schools and $20.63 \%$ or 13 are public schools. In terms of percentage distribution by province and type of school, Zamboanga del Norte has 14 private schools or $28 \%$ out of 50 while 5 or $38.46 \%$ out of 13 are public schools. Zamboanga del Sur has 12 private schools or $24 \%$ out of 50 schools while 3 or $23.08 \%$ are public schools. Zamboanga Sibugay has 8 private schools or $16 \%$ out of 50 and has only 1 or $7.69 \%$ public schools. Isabela City has 3 private schools or $6 \%$ with only 1 public school or 7.69 out of 13 . Zamboanga City has 13 private schools or $26 \%$ with 3 or $23.08 \%$ of the 13 public schools in the region.

Of these higher education institutions in the region, only five universities and colleges actually located in Zamboanga City were included as research sites: the Western Mindanao State University, Ateneo de Zamboanga University, and Universidad de Zamboanga for universities; Zamboanga State College of Marines Sciences and Technology and the Zamboanga City State Polytechnic College for the colleges. Their selection was principally based on the presence of research proofs and functional research centers. Table 1 shows the total number of higher education institutions in the whole of Region ${ }^{9}$.Table 1 . Total number of higher education institutions in region IX

\begin{tabular}{|c|c|c|c|c|c|c|c|}
\hline Area & & \multicolumn{2}{|c|}{ Private } & \multicolumn{2}{|c|}{ Public } & \multicolumn{2}{|c|}{ Total } \\
\hline & & $\mathrm{n}$ & $\%$ & $\mathrm{~N}$ & $\%$ & $\mathrm{~N}$ & $\%$ \\
\hline Zamboanga del Norte & & 14 & 28.00 & 5 & 38.46 & 19 & 30.16 \\
\hline Zamboanga del Sur & & 12 & 24.00 & 3 & 23.08 & 15 & 23.81 \\
\hline Zamboanga Sibugay & & 8 & 16.00 & 1 & 7.69 & 9 & 14.29 \\
\hline Zamboanga City & & 13 & 26.00 & 3 & 23.08 & 16 & 25.40 \\
\hline Isabela City & & 3 & 6.00 & 1 & 7.69 & 4 & 6.34 \\
\hline & Total & 50 & 100 & 13 & 100 & 63 & 100 \\
\hline
\end{tabular}

Four (4) different sets of instruments were utilized in this study. The first was a researcher-constructed matrix designed to gather data on the frequency of research undertaking per teacher/researcher, number of teacher/researcher per research work, 
and number of teachers undertaking research per school year. This matrix was designed to provide data for the first research problem, letters $a, b$, and $c$. The second instrument was also a researcher-made matrix designed to classify research undertakings and outputs. It classified data by title of research, year started and completed, type and nature of research, funding source, publication and utilization. It was designed to provide data to the third research problem, letters a, b, c, and d. The third instrument was a simple researcher-constructed two-question survey form designed to elicit existing research mechanisms and research agenda among the institutions included in the study. It was also designed to gather and provide data to the fourth problem of the research. The fourth instrument consisted of guide questions referred to as semistructured interview schedule designed to provide data on the obstacles encountered in undertaking research among teachers/researchers and on the ongoing programs for research development among the research directors or deans. The first part consisted of seven (7) guide questions for the respondent-teachers/researchers and the second part consisted of ten (10) guide questions for the research directors/deans. These guide questions were intended to provide answers to research problems 5 and 6 . Appendix A shows samples of the instruments.Content validity of all the parts of the matrices and semi-structured interview schedule were referred to a committee of three (3) experts whose recommendations were incorporated into the instruments prior to their actual administration. No test of reliability was conducted since the main instruments simply classified data taken from documents of the participating institutions except the semi-structured interview schedule, which consisted of seventeen (17) open-ended questions.

Of the areas in Region IX or the Zamboanga Peninsula, only the area of Zamboanga City was purposively chosen as the research locale since the other HEIs in the region do not have proofs of research and functional research centers. The purposive sampling was also used in the selection of respondents such as the research directors or deans and teachers/researchers with actual research outputs. Frequency and percentage were used to quantify data for the first and third research problems. Mann-Whitney U Test was used to test the significant differences of variables in the second research problem. Document analysis was resorted to answer the fifth and sixth research problems of the study. Data for Mann-Whitney U Test treatment were input for SPSS generated results. Data taken from the semi-structured interview schedule were transcribed, analyzed, and interpreted along emerging themes. Data taken from document analysis, research directors-deans, and teachers/researchers though intended to answer different research problems were triangulated. Approval to undertake the research was secured from the Research Council of the Universidad de Zamboanga that funded the study. Letters seeking approval to conduct the research were sent to the different heads of schools included in the study. Documents used in the analysis were also specified. Appointments 
Liceo Journal of Higher Education Research

were made with respondents for the distribution of the instruments, which were later retrieved. Upon retrieval of instruments, tabulations and interpretation ensued.

\section{RESULTS AND DISCUSSION}

\section{Faculty Research Performance}

\section{Number of Researches undertaken per Faculty}

\section{a.1 By Type of School (Public/Private)}

This section refers to the number of researches conducted by each teacher/ researcher in a given year over five (5) school years (2002 to 2007). In terms of school type, data revealed that across the five-year period, the number of teachers/researchers who conducted one research each year was greater than the number of those who conducted more than one research. Of the 175 teachers/researchers across the five year period, $46.3 \%$ or 81 teachers/researchers in public HEIs did only one research each year while $40 \%$ or 70 teachers/researchers in the private HEIs also undertook one research each per year. Across the same period, only $4.6 \%$ or 8 of public HEIs' teachers/ researchers and $4 \%$ or 7 of private HEIs did two researches a year. Further, only $1.7 \%$ or 3 teachers/researchers in public HEIs and $2.3 \%$ or 4 teachers/researchers in private HEIs did three researches in a given school year. Of the teachers/researchers in public HEIs, 1 did four researches and 1 with five researches in a given year.

Based on the 94 teachers/researchers who undertook research works across the fiveyear period, $6.2 \%$ or 5 teachers/researchers did one research for SY 2002-2003. In school year 2003-2004, the number increased to $14.8 \%$ or 12 teachers/researchers and further increased to $18.5 \%$ or 15 teachers/researchers in the subsequent year. In school year 2005-2006, 29.6\% or 24 teachers/researchers each had one research output. However, in school year 2006-2007 had the highest percentage of teachers/researchers $(30.9 \%$ or 25) who did one research. The number of teachers/researchers who undertook two researches in a year was very minimal. For instance, there were only $37.5 \%$ (3) in 2002$2003,12.5 \%$ (1) in $2003-2004,12.5 \%$ (1) in $2004-2005,12.5 \%$ (1) in $2005-2006$, and $25 \%$ (2) in 2006-2007. Only in school years 2005-2006 and 2006-2007 where 1 and 2 teachers/ researchers did three researches, respectively. Only in 2004-2005 where one teacher/ researcher did four researches in that year and 1 did five researches in 2002-2003. The number suggests that these researches must have been conducted in collaboration with other researchers since it would be difficult for one researcher to do it alone.

In the private HEIs among the 81 teachers/researchers who did reveal across the five-year period, $11.4 \%$ or 8 of them completed one in SY 2002-2003. The number spiraled to $28.6 \%$ or 20 in 2003-2004, higher than that in the public HEIs. A further increase of $31.4 \%$ or 22 teachers/researchers completed one research each in 2004- 
2005, still higher than that of the public HEIs. However, the number of the researchers decreased (17.1\% or 12) in 2005-2006, this time lower than that of the public HEIs. Only $11.4 \%$ or 8 teachers/researchers completed one research in 2006-2007. In 2002-2003, $14.3 \%$ or 1 did two researches, while only 1 did three researches in 2003-2004 and 20042005. No teacher/researcher completed 4 or 5 researches in a year between school years 2002-2007 in the private HEIs.

Overall, most of the 175 teachers/researchers across the five-year period completed only one (1) research a year. This situation may be attributed to a number of factors that hinder research performance. A positive reinforcement is essential to improve productivity (Mazur, 2007).

\section{b.1By Status of School (College/University)}

\begin{tabular}{|c|c|c|c|c|c|c|c|c|c|c|c|c|c|c|c|c|c|c|c|c|c|c|}
\hline \multirow[t]{4}{*}{ S.Y. } & \multicolumn{20}{|c|}{ Number of researches conducted by each researcher } & \multicolumn{2}{|c|}{ Total } \\
\hline & \multirow{2}{*}{\multicolumn{2}{|c|}{1}} & \multirow{2}{*}{\multicolumn{2}{|c|}{2}} & \multicolumn{4}{|c|}{ Public } & \multirow{2}{*}{\multicolumn{2}{|c|}{ 5-up }} & \multirow{2}{*}{\multicolumn{7}{|c|}{$2_{3}^{\text {Private }}$}} & \multirow[b]{2}{*}{4} & \multirow{2}{*}{\multicolumn{2}{|c|}{$\begin{array}{l}5- \\
\text { up }\end{array}$}} & \multirow[b]{3}{*}{$\mathrm{N}$} & \multirow[b]{3}{*}{$\%$} \\
\hline & & & & & & 3 & & 4 & & & & 1 & & 2 & & 3 & & & & & & \\
\hline & $\mathrm{f}$ & $\%$ & $\mathrm{f}$ & $\%$ & $\mathrm{f}$ & $\%$ & $\mathrm{f}$ & $\%$ & $\mathrm{f}$ & $\%$ & $\mathrm{f}$ & $\%$ & $\mathrm{f}$ & $\%$ & $\mathrm{f}$ & $\%$ & $\mathrm{f}$ & $\%$ & $\mathrm{f}$ & $\%$ & & \\
\hline $\begin{array}{c}2002- \\
2003\end{array}$ & 5 & 6.2 & 3 & 37.5 & - & - & - & - & 1 & 100 & 8 & 11.4 & 1 & 14.3 & - & - & - & - & - & - & 18 & 10.3 \\
\hline $\begin{array}{c}2003- \\
2004\end{array}$ & 12 & 14.8 & 1 & 12.5 & - & - & - & - & - & - & 20 & 28.6 & 4 & 57.1 & 1 & 25.0 & - & - & - & - & 38 & 21.7 \\
\hline $2004-$ & 15 & 18.5 & 1 & 12.5 & - & - & 1 & 100 & - & - & 22 & 31.4 & - & - & 1 & 25.0 & - & - & - & - & 40 & 22.9 \\
\hline $\begin{array}{l}2005- \\
2006\end{array}$ & 24 & 29.6 & 1 & 12.5 & 1 & 33.3 & - & - & - & - & 12 & 17.1 & - & - & 2 & 50.0 & - & - & - & - & 40 & 22.9 \\
\hline $\begin{array}{c}2006- \\
2007\end{array}$ & 25 & 30.9 & 2 & 25.0 & 2 & 66.7 & - & - & - & - & 8 & 11.4 & 2 & 28.6 & - & - & - & - & - & - & 39 & 22.2 \\
\hline Total & 81 & 100 & 8 & 100 & 3 & 100 & 1 & 100 & 1 & 100 & 70 & 100 & 7 & 100 & 4 & 100 & - & - & - & - & 175 & 100 \\
\hline
\end{tabular}

By status of school, the data revealed that the universities far outweighed the colleges in terms of the number of teachers/researchers who undertook researches across the five-year period. Of the 54 teachers/researchers in the colleges, $26.9 \%$ or 47 teachers/researchers completed one a each year over the five-year period, while $59.4 \%$ or 104 of the teachers/researchers in completed one research a year five universities. Among the colleges, $2.9 \%$ or 5 teachers/researchers did two researches. However, the number of university teachers/researchers who completed two researches a year doubled $(5.7 \%$ or 10$)$ that of the college teachers/researcher. Only $0.6 \%$ or 1 college teacher/researcher undertook 3 and 1 completed 4 researches in different year, but none did five or more researches. In $3.4 \%$ or 6 teachers/researchers undertook 3 researches a year while none did four researches in a row. Lastly, only $0.6 \%$ or 1 actually completed five researches in 2002-2003.

Of the 54 college teachers/researchers $2.1 \%$ or 1 undertook research work in 20022003 while $19.1 \%$ or 9 in 2003-2004 and 2004-2005. The bulk of teachers/researchers (46.8\% or 22) who undertook one research work a year were in 2005-2006. Around $12.8 \%$ or 6 teachers/researchers did one research work in 2006-2007. Across the five- 
Liceo Journal of Higher Education Research

year period, only 1 teacher/researcher did two researches a year while 1 researcher did 3 and 1 did 4 research works in 2005-2006 and 2004-2005, respectively. In the colleges, none did five or more researches in one year.

In universities, $11.5 \%$ or 12 out of the 104 teachers/researchers did one research in $2002-2003$. The figure increased to $22.1 \%$ or 23 in $2003-2004$ and further increased to $26.9 \%$ or 28 in 2004-2005. This figure has, however, decreased to $13.5 \%$ or 14 in 20052006. But then, an increase was noted in 2006-2007 (26.0\% or 27$)$.

Few researchers completed more than one research in a given year. For instance, in 2002-2003, only $30.0 \%$ or 3 out of 10 teachers/researchers did two researches in a given year. The figure inversed to $40.0 \%$ or 4 in 2003-2004, but none in 2004-2005 and 20052006. Again, only $30.0 \%$ or 3 did two researches in 2006-2007.

Therefore, the number of teachers/researchers doing one research a year is far greater than those doing more than one among the universities.

Table 3. Number of researches conducted by each researcher according to status of school in five school years

\begin{tabular}{|c|c|c|c|c|c|c|c|c|c|c|c|c|c|c|c|c|c|c|c|c|c|c|}
\hline \multirow{5}{*}{ S.Y. } & \multirow{2}{*}{\multicolumn{20}{|c|}{ Number of researches conducted by teacher }} & \multirow{2}{*}{\multicolumn{2}{|c|}{ Total }} \\
\hline & & & & & & & & & & & & & & & & & & & & & & \\
\hline & \multicolumn{8}{|c|}{ College } & \multicolumn{10}{|c|}{ University } & \multirow{2}{*}{\multicolumn{2}{|c|}{ 5-above }} & & \\
\hline & \multicolumn{2}{|c|}{1} & \multicolumn{2}{|c|}{2} & \multicolumn{2}{|c|}{3} & \multicolumn{2}{|c|}{4} & \multicolumn{2}{|c|}{$\begin{array}{c}5- \\
\text { above }\end{array}$} & \multicolumn{2}{|c|}{1} & \multicolumn{2}{|r|}{2} & \multicolumn{2}{|c|}{3} & \multicolumn{2}{|c|}{4} & & & \multirow[b]{2}{*}{$\mathrm{N}$} & \multirow[b]{2}{*}{$\%$} \\
\hline & $f$ & $\%$ & $\mathrm{f}$ & $\%$ & $\mathrm{~F}$ & $\%$ & $\mathrm{f}$ & $\%$ & $\mathrm{f}$ & $\%$ & $\mathrm{f}$ & $\%$ & $\mathrm{f}$ & $\%$ & $f$ & $\%$ & $\mathrm{f}$ & $\%$ & $\mathrm{f}$ & $\%$ & & \\
\hline $\begin{array}{c}2002- \\
2003\end{array}$ & 1 & 2.1 & 1 & - & - & - & - & - & - & - & 12 & $\begin{array}{c}11 . \\
5\end{array}$ & 3 & $\begin{array}{l}30 . \\
0\end{array}$ & - & - & - & - & 1 & $\begin{array}{c}10 \\
0\end{array}$ & 18 & 10.2 \\
\hline $\begin{array}{l}2003- \\
2004\end{array}$ & 9 & $\begin{array}{c}19 . \\
1\end{array}$ & 1 & - & - & - & - & - & - & - & 23 & $\begin{array}{c}22 . \\
1\end{array}$ & 4 & $\begin{array}{l}40 . \\
0\end{array}$ & 1 & $\begin{array}{c}16 . \\
7\end{array}$ & - & - & - & - & 38 & 21.7 \\
\hline $\begin{array}{c}2004- \\
2005\end{array}$ & 9 & $\begin{array}{c}19 . \\
1\end{array}$ & 1 & - & - & - & 1 & - & - & - & 28 & $\begin{array}{c}26 . \\
9\end{array}$ & - & - & 1 & $\begin{array}{c}16 . \\
7\end{array}$ & - & - & - & - & 40 & 22.9 \\
\hline $\begin{array}{c}2005- \\
2006\end{array}$ & $\begin{array}{l}2 \\
2\end{array}$ & $\begin{array}{c}46 . \\
8\end{array}$ & 1 & - & 1 & - & - & - & - & - & 14 & $\begin{array}{c}13 . \\
5\end{array}$ & - & - & 2 & $\begin{array}{c}33 . \\
3\end{array}$ & - & - & - & - & 40 & 22.9 \\
\hline $\begin{array}{l}2006- \\
2007\end{array}$ & 6 & $\begin{array}{c}12 . \\
8\end{array}$ & 1 & - & - & - & - & - & - & - & 27 & $\begin{array}{c}26 . \\
0\end{array}$ & 3 & $\begin{array}{c}30 . \\
0\end{array}$ & 2 & $\begin{array}{c}33 . \\
3\end{array}$ & - & - & - & - & 39 & 22.3 \\
\hline Total & 47 & 100 & 5 & - & 1 & - & 1 & - & - & - & 104 & 100 & 10 & 100 & 6 & 100 & - & - & 1 & - & 175 & 100 \\
\hline
\end{tabular}

2. Number of Teachers/Researchers per Research Work

a.2 By Type of School (Public/Private)

By type of school, data showed that out of 140 researches, $43.6 \%$ or 61 came from the public HEIs while $56.4 \%$ or from the private HEIs. In both cases, the number of researches with single authorship outweighed those with more than one author. Among the public HEIs, 39.3\% or 24 researches were undertaken with single authorship, while $69.6 \%$ or 55 researches were undertaken by two or more authors among the private HEIs. The public HEIs had higher number of researches with two authors $(27.9 \%$ or 17$)$ than the private HEIs $(16.5 \%$ or 13$)$. Likewise, public HEIs had higher number of researches with three authors $(24.6 \%$ or 15$)$ than private HEIs (11.4\% or 9$)$. The data showed that private HEIs have more researches with one author than public HEIs. The difference may be attributed to the availability of research funds for single authorship in the private schools. 
A closer look at the data from the public HEIs showed that in 2002-2003, 8.3\% or 2 researches out of 24 had single authorship and 20.8\% or 5 in 2003-2004. Again, in 2004-2005 only $8.3 \%$ or 2 researches had single authorship, but it increased to $33.3 \%$ or 8 researches in 2005-2006. The 2006-2007 had $29.2 \%$ or 7 researches with single authorship. Of the 17 researches with two authors, $17.6 \%$ or 3 researches were done in school year 2002-2003, $11.8 \%$ or 2 in 2003 to 2006, and $47.0 \%$ or 8 in 2006-2007. Fifteen researches with three authors were done as follows: $6.7 \%$ or 1 in $2002-2003,20.0 \%$ or 3 in $2003-2004,33.3 \%$ or 5 in $2004-2005,20.0 \%$ or 3 in 2005-2006 and 2006-2007.

Data from the private HEIs revealed that the bulk of the researches were single authored. Of the 55 researches with single authorship, 9.1\% or 5 were done in 2002$2003,40.0 \%$ or 22 in $2003-2004,21.8 \%$ or 12 in $2004-2005,18.2 \%$ or 10 in $2005-2006$, and $10.9 \%$ or 6 in 2006-2007. Researches done by two authors were relatively lower in private schools (13 researches) than those in the public HEIs. Of the total number, 38.5\% or 5 were done in 2003-2004, 23.0\% or 3 in 2004-2005, and 38.5\% or 5 in 2005-2006. Only 9 researches were authored by three researchers.

Overall, the number of researches with single authorship was highest across type of school and equally highest among the private schools. More teachers/researchers in the private schools did research individually than those in the public schools.

Table 4. Number of researchers per research work across type of school in five school years

\begin{tabular}{|c|c|c|c|c|c|c|c|c|c|c|c|c|c|c|c|c|c|c|c|c|c|c|}
\hline \multirow[t]{3}{*}{ S.Y. } & \multicolumn{20}{|c|}{ Number of research work per researcher } & \multicolumn{2}{|c|}{ Total } \\
\hline & \multicolumn{2}{|c|}{1} & \multicolumn{2}{|c|}{2} & \multicolumn{2}{|c|}{3} & \multicolumn{2}{|c|}{4} & \multicolumn{2}{|c|}{ 5-above } & \multicolumn{2}{|c|}{1} & \multicolumn{2}{|c|}{2} & \multicolumn{2}{|c|}{3} & \multicolumn{2}{|c|}{4} & \multicolumn{2}{|c|}{5 -above } & & \\
\hline & $\mathrm{f}$ & $\%$ & f & $\%$ & $\mathrm{f}$ & $\%$ & $\mathrm{f}$ & $\%$ & $f$ & $\%$ & $\mathrm{f}$ & $\%$ & $\mathrm{f}$ & $\%$ & $\mathrm{f}$ & $\%$ & $\mathrm{~F}$ & $\%$ & $\mathrm{f}$ & $\%$ & $\mathrm{~N}$ & $\%$ \\
\hline $\begin{array}{l}2002- \\
2003\end{array}$ & 2 & $\begin{array}{l}8 . \\
3\end{array}$ & 3 & $\begin{array}{c}17 \\
6\end{array}$ & 1 & 6.7 & 1 & $\begin{array}{c}50 . \\
0\end{array}$ & - & - & 5 & 9.1 & - & - & - & - & - & - & 1 & 50.0 & 13 & 9.3 \\
\hline $\begin{array}{l}2004- \\
2005\end{array}$ & 2 & $\begin{array}{l}8 . \\
3\end{array}$ & 2 & $\begin{array}{c}11 . \\
8\end{array}$ & 5 & $\begin{array}{c}33 . \\
3\end{array}$ & - & - & - & - & 12 & $\begin{array}{c}21 . \\
8\end{array}$ & 3 & $\begin{array}{c}23 . \\
0\end{array}$ & 4 & $\begin{array}{c}66 . \\
7\end{array}$ & - & - & - & - & 28 & $\begin{array}{c}20 . \\
0\end{array}$ \\
\hline $\begin{array}{l}2005- \\
2006\end{array}$ & 8 & $\begin{array}{c}33 \\
.3\end{array}$ & 2 & $\begin{array}{c}11 . \\
8\end{array}$ & 3 & $\begin{array}{c}20 . \\
0\end{array}$ & - & - & - & - & 10 & $\begin{array}{c}18 . \\
2\end{array}$ & 5 & $\begin{array}{c}38 . \\
5\end{array}$ & 4 & - & - & - & - & - & 32 & $\begin{array}{c}22 . \\
9\end{array}$ \\
\hline Total & 24 & $\begin{array}{c}10 \\
0\end{array}$ & 17 & 100 & 15 & $\begin{array}{c}10 \\
0\end{array}$ & 2 & 100 & 3 & $\begin{array}{c}10 \\
0\end{array}$ & 55 & 100 & 13 & 100 & 9 & 100 & - & - & 2 & 100 & $\begin{array}{c}14 \\
0\end{array}$ & 100 \\
\hline
\end{tabular}

\section{b.2 By Status of School (College/University)}

Of the total researches, $73.6 \%$ or 103 researches came from the universities while $26.4 \%$ or 37 from college in terms of the number of authorship per research in a year, of the 37 researches in the colleges, $54.1 \%$ or 20 were done with single author while $57.3 \%$ or 59 out of 103 researches in the universities were done with one author. Among the colleges, $10.8 \%$ or 4 researches had 2 authors, $21.6 \%$ or 8 had $3,2.7$ or 1 had 4 , and $10.8 \%$ or 4 had 5 . On the other hand, among the 
Liceo Journal of Higher Education Research

universities, $57.3 \%$ or 59 researches had single author, $24.3 \%$ or 25 had $2,15.5 \%$ or 16 had $3,0.7 \%$ or 1 had 4 and $1.9 \%$ or 2 had 5 more.

Still among the colleges, of the 37 researches, $50.1 \%$ or 20 researches had 1 author. In 2002-2003, $10.0 \%$ or 2 researches had one author each; $2003-2004,20.0 \%$ or $4 ; 2004-2005,10.0 \%$ or $2 ; 2005-2006,40.0 \%$ or 8 ; and $2006-200720.0 \%$ or 4 . Around $10.8 \%$ or 4 had 2 authors and were distributed by year as follows: $50.0 \%$ or 2 in $2003-2004,25.0 \%$ or 1 in 2004-2005, 25.0\% or 2 in 2005-2006, and $12.5 \%$ or 1 in 2006-2007. Of the 8 researches with 3 researchers each, 12.5\% or 1 was done in $2003-2004,50.0 \%$ or 4 in $2004-2005,25.0 \%$ or 2 in $2005-2006$, and $12.5 \%$ or 1 in 2006-2007. There were only 1 and 4 researches with 4 and 5 or more researchers, respectively.

Of the 103 researches in the universities, $57.3 \%$ or had one author, of which $8.8 \%$ or 5 were done in $2002-2003,40.4 \%$ or 23 in $2003-2004,21.0 \%$ or 12 in 2004$2005,14.0 \%$ or 10 in $2005-2006$, and $15.8 \%$ or 9 in $2006-2007$. There were $24.3 \%$ or 25 researches with two authors, which $12.0 \%$ or 3 were done in $2002-2003,20.0 \%$ or 23 in $2003-2004,16.0 \%$ or 4 in 2004-2005, 20.0\% or 5 in 2005-2006, and $32.0 \%$ or 8 in $2006-2007$. There were $15.5 \%$ or 16 researches with 3 authors, of which $10.0 \%$ or 1 was done in $2002-2003,20.0 \%$ or 2 in $2003-2004,30.0 \%$ or 5 in $2004-2005,10.0 \%$ or 5 in 2005-2006, and $30.0 \%$ or 3 in 2006-2007. There were only 1 and 2 researches that were conducted by 4 and 5 or more researchers, respectively.

\section{Number of Teacher/Researcher Undertaking Research Each Year}

\section{a.3. By Type of School (Public/Private)}

On the average, the public schools employed greater number of teachers (795) across the five-year period than the private schools (607). The average number of public teachers who undertook research was 20 against 12 private teachers. The public schools showed an average percentage of $2.5 \%$ research-performing teachers, slightly higher than the $2.0 \%$ for private schools.

The public schools employed a total of 748 teachers in 2002-2003, of whom only $1.2 \%$ or 9 actually did research. In 2003-2004, the number increased to 772 , of whom $1.7 \%$ or 13 teachers did research. The number increased to 779 in $2004-$ 2005 , of whom $2.4 \%$ or 19 did research. In 2005-2006, there were 785 employed public schools teacher, of them $3.6 \%$ or 28 did research. And in 2006-2007, of the 893 employed teachers, $3.4 \%$ or 30 of them did research. A steady increase in the number of public school teachers doing research over the five-year period was noted.

In contrast, a reverse trend was observed in the private schools. While there was an increase in the number of teachers doing research in the first three years, a decline was observed of in the last two years. In 2002-2003, of the 641 teachers 
private school teachers, $1.2 \%$ or 8 of them did research. An increase was seen in 2003-2004 when out of the 616 teachers $3.6 \%$ or 22 did research. As the number of employed teachers declined to 613 in 2004-2005, 2.4\% or 15 undertook research. In $2005-2006$, of the 560 employed teachers, $1.6 \%$ or 9 did research while only $1.2 \%$ or 7 did research in 2006-2007. As observed, the public schools employed more teachers than the private schools and actually have slightly higher number of teachers with research outputs than the private schools.

Table 5. Number of faculty members undertaking research per school year across type of school in five

\begin{tabular}{ccccccc}
\multicolumn{7}{c}{ years } \\
\cline { 2 - 7 } S.Y. & \multicolumn{9}{c}{ Public } & \multicolumn{3}{c}{ Private } \\
& No. of & $\begin{array}{c}\text { No. } \\
\text { Faculty }\end{array}$ & Percentage & No. of & No. & Percentage \\
& Faculty & Undertaking & \\
$2002-2003$ & 748 & 9 & 1.2 & 641 & 8 & 1.2 \\
$2003-2004$ & 772 & 13 & 1.7 & 616 & 22 & 3.6 \\
$2004-2005$ & 779 & 19 & 2.4 & 613 & 15 & 2.4 \\
$2005-2006$ & 785 & 28 & 3.6 & 560 & 9 & 1.6 \\
$2006-2007$ & 893 & 30 & 3.4 & 605 & 7 & 1.2 \\
Average & 795.4 & 19.8 & 2.5 & 607 & 12.2 & 2.0 \\
\hline
\end{tabular}

\section{b.2 By Status of School (College/University)}

It is evident that the universities not only had higher number of employed teachers but also higher number of teachers with research works than the colleges. Across the five-year period, an average of 206 teachers were employed in the colleges while 1,150 in the universities. The colleges had an average of $4.3 \%$ or 11 teachers who did research over the five year period while an average of $2.9 \%$ or 21 university teachers did research for the same period. Although lower in average percentage, the universities had higher number of teachers who did research than the college.

By year, among the colleges, out of the 251 employed teachers in 2002-2003, $0.8 \%$ or 2 did research. The percentage increased to $3.9 \%$ or 10 in $2003-2004$. A slight increase was noted in 2004-2005 with 252 employed teachers of whom $4.4 \%$ or 11 did research. A further increase was observed in 2005-2006 with 252 employed teachers of whom $9.5 \%$ or 24 did research. But in 2006-2007, a marked decline in the number of teachers doing research was observed with 252 employed of whom teachers only $2.8 \%$ or 7 did research.

Among the universities, of the total number of employed teachers in 20022003 , only $1.3 \%$ or 15 did research while $2.2 \%$ or 25 did research in the subsequent year. In 2004-2005, of the 1,140 employed teachers, $2.0 \%$ or 23 did research. In 20052006, a marked decline in the number of employed teachers and in the number of teachers doing research was also (6.7\% or 13 teachers). SY 2006-2007 saw the highest number of employed teachers as well as the number of those who did research (2.4\% or 30 teachers). As noted, the universities employed more teachers and had more teachers with research outputs than the colleges. This finding may be attributed to the research requirement imposed on the faculty in universities. 
Liceo Journal of Higher Education Research

Table 6 Number of faculty members undertaking research per school year across status of school in five school years

\begin{tabular}{|c|c|c|c|c|c|c|}
\hline \multirow[t]{2}{*}{ S.Y. } & \multicolumn{3}{|c|}{ College } & \multicolumn{3}{|c|}{ University } \\
\hline & $\begin{array}{l}\text { No. of } \\
\text { Faculty }\end{array}$ & $\begin{array}{c}\text { No. } \\
\text { Undertaking }\end{array}$ & Percentage & No. of Faculty & $\begin{array}{c}\text { No. } \\
\text { Undertaking }\end{array}$ & Percentage \\
\hline $2002-2003$ & 251 & 2 & 0.8 & 1,138 & 15 & 1.3 \\
\hline $2003-2004$ & 251 & 10 & 3.9 & 1,137 & 25 & 2.2 \\
\hline 2004-2005 & 252 & 11 & 4.4 & 1,140 & 23 & 2.0 \\
\hline $2005-2006$ & 252 & 24 & 9.5 & 1,093 & 13 & 6.7 \\
\hline $2006-2007$ & 252 & 7 & 2.8 & 1,246 & 30 & 2.4 \\
\hline Average & 206.4 & 10.8 & 4.3 & $1,150.8$ & 21.2 & 2.9 \\
\hline
\end{tabular}

\section{Comparing Research Performances of Schools}

1.a Number of Researches Undertaken by Teacher-Researchers

a.1. According to Type of School (Public/Private)

As shown in Table 8, there was a significant difference in the number of researches undertaken by the faculty in private and public schools as revealed by the $Z$ value of -1.982 at .05 level of significance, which led to the rejection of the null hypothesis. However, based on the mean rank, the public schools had a slightly lower number of researches conducted than the private schools across the five-year period. The private school research outputs had a mean rank of 74.73 while the public school outputs had a mean rank of 63.28 .

Table 7. Mann-whitney U test for two independent samples: number of researches undertaken by the faculty in private and public HEIs

\begin{tabular}{ccccccc}
\hline Type & $\mathrm{N}$ & Mean Rank & Rank Sum & Z-test & $\mathrm{P}<.05$ & Decision \\
\hline Public & 74 & 63.28 & 4683 & -1.982 & .047 & Significant \\
Private & 62 & 74.73 & 4683 & & & \\
\hline
\end{tabular}

\section{According to Status of School (College/University)}

Results of the Mann-Whitney U Test for Two Independent Samples revealed a significant difference in the number of researches colleges $(m=54.86)$ and universities ( $\mathrm{m}=75.25)$. A $\mathrm{Z}$ value of -3.337 at .05 level of significance was recorded, thus rejecting the null hypothesis. This finding implies that the number of researches in the universities is significantly higher than that in the colleges across the five-year period.

Table 8. Mann-whitney U test for two independent samples: number of researches undertaken by the teacher-

\begin{tabular}{ccccccc}
\multicolumn{7}{c}{ researchers in the colleges and universities } \\
\hline Type & $\mathrm{N}$ & Mean Rank & Rank Sum & Z-test & $\mathrm{P}<.05$ & Decision \\
\hline College & 45 & 54.86 & 2468.50 & -3.337 & .001 & Significant \\
University & 91 & 75.25 & 6847.50 & & & \\
\hline
\end{tabular}

\section{Classification of Research Centers' Outputs}

1.a Nature and Type of Research

a.1. By Type of School (Public/Private)

Of the 104 researches considered institutional in nature, $55.8 \%$ or 58 researches were from private schools while $42.2 \%$ or 46 were from the public schools. By comparison, the private schools had more institutional researches than the public 
schools. Of the 32 social researches, $65.6 \%$ or 21 researches were from the private schools while $34.4 \%$ or 11 researches were from the public schools. Comparatively, the private schools had more social researches than the public schools. However, only the public schools had 4 researches on grants based on available data.

As to the type of research, most researches across types of school were descriptive. Of the 100 descriptive researches, $26.0 \%$ or 26 were quantitative and of which $65.4 \%$ or 17 researches were from the private schools and $34.6 \%$ or 9 from the public schools. Qualitative researches accounted for $35.0 \%$ or 49 of which $87.8 \%$ or 43 were from the private schools while $12.2 \%$ or 6 from the public schools. The remaining $25.3 \%$ or 25 researches were a combination of quantitative and qualitative research of which $48.0 \%$ or 12 were from the private schools while $52.0 \%$ or 13 from the public schools. Only 1 research from the private school was historical while $84.6 \%$ or 33 out of the 39 experimental researches were from the public schools and $15.4 \%$ from the private schools. Overall, most researches were institutional and few were social and grants. Also, most were descriptive and few were experimental and historical across types of school.

Table 9. Research undertaking and outputs of research centers according to nature and type of research across type

\begin{tabular}{|c|c|c|c|c|c|c|c|c|c|c|c|c|c|c|c|c|}
\hline \multirow{4}{*}{$\begin{array}{l}\text { School } \\
\text { Type }\end{array}$} & \multicolumn{6}{|c|}{ Nature } & \multicolumn{10}{|c|}{ Type } \\
\hline & \multirow{2}{*}{\multicolumn{2}{|c|}{$\begin{array}{l}\text { Institution } \\
\quad \text { al }\end{array}$}} & \multirow{2}{*}{\multicolumn{2}{|c|}{ Social }} & \multirow{2}{*}{\multicolumn{2}{|c|}{ Grants }} & \multicolumn{4}{|c|}{$\begin{array}{cc} & \text { Descriptive } \\
\text { Quantitat } & \text { Qualitati }\end{array}$} & \multirow{2}{*}{\multicolumn{2}{|c|}{$\begin{array}{c}\text { Combina } \\
\text { tion }\end{array}$}} & \multirow{2}{*}{\multicolumn{2}{|c|}{ Historical }} & \multirow{2}{*}{\multicolumn{2}{|c|}{$\begin{array}{l}\text { Experim } \\
\text { ental }\end{array}$}} \\
\hline & & & & & & & & titat & & litati & & & & & & \\
\hline & $\mathrm{f}$ & $\%$ & $\mathrm{f}$ & $\%$ & $\mathrm{f}$ & $\%$ & $\mathrm{~F}$ & $\%$ & $\mathrm{f}$ & $\%$ & $\mathrm{f}$ & $\%$ & $\mathrm{f}$ & $\%$ & $\mathrm{f}$ & $\%$ \\
\hline Public & 46 & 44.2 & $\begin{array}{l}1 \\
1\end{array}$ & $\begin{array}{c}34 . \\
4\end{array}$ & 4 & 100 & 9 & $\begin{array}{c}34 . \\
6\end{array}$ & 6 & $\begin{array}{c}12 . \\
2\end{array}$ & 13 & $\begin{array}{c}52 . \\
0\end{array}$ & - & - & $\begin{array}{l}3 \\
3\end{array}$ & $\begin{array}{c}84 . \\
6\end{array}$ \\
\hline Private & 58 & 55.8 & $\begin{array}{l}2 \\
1\end{array}$ & $\begin{array}{c}65 \\
6\end{array}$ & - & - & 17 & $\begin{array}{c}65 . \\
4\end{array}$ & 43 & $\begin{array}{c}87 . \\
8\end{array}$ & 12 & $\begin{array}{c}48 . \\
0\end{array}$ & 1 & 100 & 6 & $\begin{array}{c}15 . \\
4\end{array}$ \\
\hline Total & 104 & 100 & $\begin{array}{l}3 \\
2\end{array}$ & 100 & 4 & 100 & 26 & 100 & 49 & 100 & 25 & 100 & 1 & 100 & $\begin{array}{l}3 \\
9\end{array}$ & 100 \\
\hline
\end{tabular}

a.2. By Status of School

As to the nature of research, most researches were institutional (74.3\% or 104) period. Universities had higher number of institutional researchers $(68.3 \%$ or 71$)$ than the colleges (31.7\% or 33). Among the 32 social researches, $93.8 \%$ or 30 were from the universities and only $6.2 \%$ or 2 from the colleges. However, in terms of grants, $75.0 \%$ or 3 researches comes from the college while only $25.0 \%$ or 1 research from a university.

As to the type of research, $18.6 \%$ or 26 researches were quantitative, $35 \%$ or 49 were qualitative, and $17.9 \%$ or 25 were a combination of quantitative and qualitative. Only $0.7 \%$ or 1 was historical and $27.9 \%$ or 39 were experimental. Of the 26 quantitative researches, $65.4 \%$ or 17 were from the universities while $34.6 \%$ 
or 9 by the colleges. All of the 49 qualitative researches were conducted by the universities. Combination of research type was mostly done by the universities, $88.0 \%$ or 22 of their researches were under this type.

One historical research was done a university (1 research). Colleges did more experimental researches than the universities $(66.7 \%$ or 26 and $33.3 \%$ or 13 , respectively). On the one hand, the findings suggest that the colleges were more specialized in their choice of research type than the universities, which in part determines the nature of the institutions. On the other hand, the universities were more varied in their fields of specialization as reflected by their research output types.

Table 10. Research undertaking and outputs of research centers according to nature and type of research across status school

\begin{tabular}{|c|c|c|c|c|c|c|c|c|c|c|c|c|c|c|c|c|}
\hline \multirow{3}{*}{$\begin{array}{l}\text { School } \\
\text { Status }\end{array}$} & \multicolumn{6}{|c|}{ Nature } & \multicolumn{10}{|c|}{ Type } \\
\hline & \multicolumn{2}{|c|}{ Institutional } & \multicolumn{2}{|c|}{ Social } & \multicolumn{2}{|c|}{ Grants } & \multicolumn{2}{|c|}{ Quantitative } & \multicolumn{2}{|c|}{$\begin{array}{l}\text { Descriptive } \\
\text { Qualitative }\end{array}$} & \multicolumn{2}{|c|}{ Combination } & \multicolumn{2}{|c|}{ Historical } & \multicolumn{2}{|c|}{ Experimental } \\
\hline & $\mathrm{F}$ & $\%$ & $\mathrm{f}$ & $\%$ & $\mathrm{f}$ & $\%$ & $\mathrm{f}$ & $\%$ & $f$ & $\%$ & f & $\%$ & $\mathrm{f}$ & $\%$ & $f$ & $\%$ \\
\hline College & 33 & 31.7 & 2 & 6.2 & 3 & $\begin{array}{c}75 . \\
0\end{array}$ & 9 & 34.6 & - & & 3 & 12.0 & - & - & 26 & 66.7 \\
\hline University & 71 & 68.3 & $\begin{array}{l}3 \\
0\end{array}$ & $\begin{array}{c}93 . \\
8\end{array}$ & 1 & $\begin{array}{c}25 . \\
0\end{array}$ & 17 & 65.4 & 49 & 100 & 22 & 88.0 & 1 & 100 & 13 & 33.3 \\
\hline Total & $\begin{array}{c}10 \\
4\end{array}$ & 100 & $\begin{array}{l}3 \\
2\end{array}$ & 100 & 4 & 100 & 26 & 100 & 49 & 100 & 25 & 100 & 1 & 100 & 39 & 100 \\
\hline
\end{tabular}

\section{Type of Funding Source}

\section{2.a. By Type of School (Public/Private)}

Out of 140 researches, $76.4 \%$ or 107 were school-funded, of which $63.6 \%$ or 68 were researches of the private schools while $36.4 \%$ or 39 were researches of the public schools. As revealed, private schools have more school-funded researches than the public schools. On the other hand, self-funded researches were higher in public schools ( $87.5 \%$ or 7 ) than in private where $87.5 \%$ or 7 out of the 8 researches were from public schools and only $12.5 \%$ or 1 was from the private schools $(40.0 \%$ or 10). Institutional funding of researches depends largely on the budgetary allocations of the institutions and on school's priority thrust. The presence of a large number of institutionally funded researches reveals that schools in the area lack linkaging and networking with funding agencies.

Table 11. Research undertaking and outputs of research centers according to type of funding source across type of school

\begin{tabular}{ccccccccccc}
\hline \multicolumn{1}{c}{ School } & \multicolumn{9}{c}{ Funding Source } & \multicolumn{4}{c}{ Total } \\
Type & \multicolumn{2}{c}{ Self-funded } & \multicolumn{2}{c}{ School-funded } & \multicolumn{2}{c}{ Outsourced } & \multicolumn{2}{c}{ Others } & & \\
& $\mathrm{f}$ & $\%$ & $\mathrm{~F}$ & $\%$ & $\mathrm{f}$ & $\%$ & $\mathrm{f}$ & $\%$ & $\mathrm{~N}$ & $\%$ \\
\hline Public & 7 & 87.5 & 39 & 36.4 & 15 & 60.0 & - & - & 61 & 43.6 \\
Private & 1 & 12.5 & 68 & 63.6 & 10 & 40.0 & - & - & 79 & 56.4 \\
$\quad$ Total & 8 & 100 & 107 & 100 & 25 & 100 & - & - & 140 & 100 \\
\hline
\end{tabular}




\section{2.b By Status of School}

Most researches in universities and colleges were school-funded. Out of the 140 researches, $76.4 \%$ or 79 researches were school-funded. Universities funding for their researches accounted for $73.8 \%$ or 79 of their researches. The colleges funding for their researches accounted for $26.2 \%$ or 28 of their researches. However, the colleges had higher self-funded researches $(75.0 \%$ or 6$)$ in comparison with the universities. Of the 25 outsourced researches, $88.0 \%$ or 22 were researches of the universities while only $12.0 \%$ or 3 were researches of the colleges. The lack of outsourced funding may be attributed to poor linkaging or networking. Fetalver's (2003) study cited similar analysis in which schools were found to be weak in research networking and linkaging.

Table 12. Research undertaking and outputs of research centers according to type of funding source across status of

\begin{tabular}{ccccccccccc}
\hline \multicolumn{1}{c}{ school } \\
\hline School & \multicolumn{1}{c}{ Funding Source } & \multicolumn{3}{c}{ Total } \\
Status & \multicolumn{1}{c}{ Self-funded } & \multicolumn{1}{c}{ School-funded } & \multicolumn{2}{c}{ Outsourced } & \multicolumn{2}{c}{ Others } & & \\
& $\mathrm{f}$ & $\%$ & $\mathrm{~F}$ & $\%$ & $\mathrm{f}$ & $\%$ & $\mathrm{f}$ & $\%$ & $\mathrm{~N}$ & $\%$ \\
\hline College & 6 & 75.0 & 28 & 26.2 & 3 & 12.0 & - & - & 37 & 26.4 \\
University & 2 & 25.0 & 79 & 73.8 & 22 & 88.0 & - & - & 103 & 73.6 \\
$\quad$ Total & 8 & 100 & 107 & 100 & 25 & 100 & - & - & 140 & 100 \\
\hline
\end{tabular}

\section{Type of Publication}

3.a. By Type of School

HEIs published their research outputs in school journals (in-house) and refereed journals (external). Based on the data, 92.1\% or 129 researches across types of school were published in school journals (in-house) while only $7.9 \%$ or 11 researches were published in refereed journals. The term school journal may include other type of in-house publications that are not necessarily termed journal. Of the 129 researches published in-house, $60.5 \%$ or 78 researches while $39.5 \%$ or 51 researches were that of the private schools while $39.5 \%$ or 51 were the public schools. While the number of refereed researches was minimal, most of them ( $90.9 \%$ or 10 out of 11 ) were from the public schools. Only $9.1 \%$ or 1 research of one college was published in refereed journal. HEIs did not have their own refereed journal that conforms to international standard and has ISI certification.

Table 13. Research undertaking and outputs of research centers according to type of publication across type of school

\begin{tabular}{|c|c|c|c|c|c|c|c|c|}
\hline \multirow{3}{*}{$\begin{array}{c}\text { School } \\
\text { Type }\end{array}$} & \multicolumn{6}{|c|}{ Type of Publication } & \multicolumn{2}{|c|}{ Total } \\
\hline & \multicolumn{2}{|c|}{ School Journal } & \multicolumn{2}{|c|}{ Refereed Journal } & \multicolumn{2}{|c|}{ Others } & & \\
\hline & $\mathrm{f}$ & $\%$ & $\mathrm{~F}$ & $\%$ & $\mathrm{~F}$ & $\%$ & $\mathrm{~N}$ & $\%$ \\
\hline Public & 51 & 39.5 & 10 & 90.9 & - & - & 61 & 43.6 \\
\hline Private & 78 & 60.5 & 1 & 9.1 & - & - & 79 & 56.4 \\
\hline Total & 129 & 100 & 11 & 100 & - & - & 140 & 100 \\
\hline
\end{tabular}

\section{3.b. By Status of School}

University researches $(73.6 \%$ or 103$)$ far outweighed college researches (26.4\% or 37 ). But, still $92.1 \%$ or 129 researches were published in-house while 
Liceo Journal of Higher Education Research

$7.9 \%$ or 11 were published in refereed journals. Of the researches published in in-house journals, $78.3 \%$ or 101 were university researches and $21.7 \%$ or 28 were college researches. However, of the 11 researches that were published in refereed journals, $81.8 \%$ or 9 were college researches while only $18.2 \%$ or 2 were university researches.

Overall, most research outputs were confined within the institutions and had limited circulation. In-house publication does not have national or international appeal, hence limits the possibility of a wider utilization of research outputs. According to Huberman (1992) and Kaestle (1993), more than the packaging of the findings, the engagement of the researcher in disseminating findings has an impact on whether those findings are acknowledged and considered by potential users.

Table 14. Research undertaking and outputs of research centers according to type of publication across status of school

\begin{tabular}{|c|c|c|c|c|c|c|c|c|}
\hline \multirow{3}{*}{$\begin{array}{l}\text { School } \\
\text { Status }\end{array}$} & \multicolumn{6}{|c|}{ Type of Publication } & \multirow{2}{*}{\multicolumn{2}{|c|}{ Total }} \\
\hline & \multicolumn{2}{|c|}{ School Journal } & \multicolumn{2}{|c|}{ Refereed Journal } & \multicolumn{2}{|c|}{ Others } & & \\
\hline & $\mathrm{f}$ & $\%$ & $\mathrm{~F}$ & $\%$ & $\mathrm{f}$ & $\%$ & $\mathrm{~N}$ & $\%$ \\
\hline College & 28 & 21.7 & 9 & 81.8 & - & - & 37 & 26.4 \\
\hline University & 101 & 78.3 & 2 & 18.2 & - & - & 103 & 73.6 \\
\hline Total & 129 & 100 & 11 & 100 & - & - & 140 & 100 \\
\hline
\end{tabular}

\section{Stakeholders of Research Outputs}

4.a. By Type of School

As to the type of school, the private schools (58.2\% or 57 of researcher) had higher institutional utilization than the public schools (41.8\% or 41 of their researchers). However, public schools had more researches (68.7\% or 46 researches).

The more research outputs are confined within the school, the more is the possibility of its non-utility or at least its limited utility. Since more researches are simply presented within the sponsoring schools, research disseminations are then limited to the policy-makers only when such outputs relate to the institutional priority. In this case, Furhman (1992) explained that providing research information to practitioners (in wider area and scope) in an accessible form is only the beginning; providing venues for exploration, reflection, implementation, and more reflection are necessary for educational change and improvement to occur.

Table 15. Research outputs of research centers according to stakeholders by type of school

\begin{tabular}{|c|c|c|c|c|}
\hline \multirow{3}{*}{$\begin{array}{c}\text { School } \\
\text { Type }\end{array}$} & \multicolumn{4}{|c|}{ Stakeholders Research Utilization } \\
\hline & \multicolumn{2}{|c|}{ School-utilized } & \multicolumn{2}{|c|}{ Utilized by Other Agencies } \\
\hline & $\mathrm{f}$ & $\%$ & $\mathrm{f}$ & $\%$ \\
\hline Public & 41 & 41.8 & 46 & 68.7 \\
\hline Private & 57 & 58.2 & 21 & 31.3 \\
\hline Total & 98 & 100 & 67 & 100 \\
\hline
\end{tabular}




\section{4.b. By Status of School}

Of the 98 school-utilized research outputs, $38.8 \%$ or 38 were college researches while $61.2 \%$ of 60 were university researches. The quantity of university researches presented for utilization to other agencies was slightly higher (50.7\% or 34) than the college researches (49.3\% or 33). Overall, the number of researches (98) presented for school utilization was far greater than those (67) presented to other agencies for utilization.

Table 16. Research outputs of research centers according to stakeholders by status of school

\begin{tabular}{lccccc}
\hline & $\begin{array}{c}\text { School } \\
\text { Type }\end{array}$ & \multicolumn{4}{c}{ Stakeholders Research Utilization } \\
& & $\mathrm{f}$ & \multicolumn{2}{c}{$\begin{array}{c}\text { School-utilized } \\
\text { Utilized by Other Agencies } \\
\%\end{array}$} \\
\hline College & & 38 & 38.8 & $\mathrm{f}$ & 49.3 \\
University & 60 & 61.2 & 34 & 50.7 \\
& \multirow{2}{*}{ Total } & 98 & 100 & 67 & 100 \\
\hline
\end{tabular}

\section{Research Agenda and Established Research Mechanisms}

\section{Vision, Mission and Research Agenda}

All HEIs covered in the research have their respective vision, mission, and research agenda. Generally, the research agenda of all HEIs have marked similarity, that is, the focus is the generation of empirical knowledge as aid to the academic disciplines. Reliance is laid on linking academic and external knowledge. Similarities were also evident in the manner how the nature of the school and the curricular offerings reflected in the research agenda. However, in terms of specific research priorities, HEIs showed marked differences in their research agenda. For instance, the Zamboanga State College of Marine Sciences and Technology or ZSCMST, being a maritime state college, includes research topics that are specifically related to maritime disciplines and marine biology issues.

The issues addressed are strictly scientific that included development of a monitoring system for EEZ and off-shore fisheries, oceanographic investigation, exploratory fishing for tuna and tuna-like species, fish aggregating devise (FAD), socio-economic and investment studies, development of value-added products, development of new processing technologies, processing of seaweeds, development of quality standard, characterization and control of fish spoilage, detoxification of biologically and chemically contaminated fish and fishery products, and related fields. Appendix F shows the Research Agenda of the ZSCMST.

The Western Mindanao State University or WMSU, being a state university of diversified disciplines, possesses research agenda enriched with multi-disciplinary research topics ranging from educational research, agricultural research, health 
research, socio-economic, political and cultural research, science and technology research, and environment studies. Appendix D shows the Research Agenda of WMSU. The Zamboanga State Polytechnic College or ZSPC, also a government school, has a more explicit and integrated research agenda. It has rather broad research issues that do not simply relate to its course offerings. The college integrated the concerns of CHED, DBM, PASUC, and its own research thrusts as its research agenda, which covered science and technology agenda for national development, Zonal Research Center prioritized research and development, the National Research Council of the Philippines, National Science and Technology Plan, and research and development priorities of the college, each with more specific sub-issues. Appendix E shows the Research Agenda of ZCSPC.

The Ateneo de Zamboanga University or ADZU has a short but general list of research priorities, which are multi-disciplinary, covering topics on peace and development, sustainable development, health and development, education and development, business and entrepreneurship, science and technology, gender and development, history and culture. Its research agenda are geared towards social and qualitative researches. Appendix B shows the Research Agenda of ADZU.

The Universidad de Zamboanga or UZ has mainly two (2) research priorities divided into institutional and social priorities, each with sub-themes. The institutional research priorities include instruction and curriculum; physical plant, research and extension, and entrepreneurial management education whereas the social research priorities include economic development, political development, social development, and environmental protection, conservation and development. Sample evidence of all these Vision, Mission, and Research Agenda are appended in this study.

Table 17. Established mechanisms and research agenda across all schools

\begin{tabular}{|c|c|c|c|c|c|c|}
\hline \multirow[t]{2}{*}{ School } & \multicolumn{4}{|c|}{ Mechanisms } & \multicolumn{2}{|c|}{ Research Agenda } \\
\hline & $\begin{array}{c}\text { College Dean } \\
\text { Approval }\end{array}$ & $\begin{array}{c}\text { Research Panel } \\
\text { Approval }\end{array}$ & $\begin{array}{c}\text { Research } \\
\text { Council } \\
\text { Approval }\end{array}$ & $\begin{array}{l}\text { Budget } \\
\text { Officer }\end{array}$ & With & Without \\
\hline ADZU & $\checkmark$ & $\checkmark$ & $\checkmark$ & & $\checkmark$ & \\
\hline $\mathrm{UZ}$ & $\checkmark$ & $\checkmark$ & $\checkmark$ & & $\checkmark$ & \\
\hline WMSU & $\checkmark$ & $\checkmark$ & $\checkmark$ & & $\checkmark$ & \\
\hline ZSCMST & $\checkmark$ & $\checkmark$ & $\checkmark$ & & $\checkmark$ & \\
\hline ZSPC & $\checkmark$ & & & $\checkmark$ & $\checkmark$ & \\
\hline
\end{tabular}

\section{Research Proposal Application System}

Each of the procedures involved in the processing of research proposals in each HEI is uniquely different, the reason being institutional differences. These procedures are briefly treated below. In the case of the ZSCMST, a memorandum, 
Guidelines on the Conduct of Research and Extension Activities and Related Programs of the College, provides for the specific procedure in the treatment of research proposals. The College President and the Head of the Office of Research and Extension are key figures in this process.

All proposals both internally and externally funded have to go through the Office of the Research and Extension for the initial stage and the Office of the College President for final approval. A special body similar to what is commonly called as Research Panel, which in this case has been termed Research Commodity Review Group or RCRG, assists in the review of the submitted proposals before they are implemented. The primary function of the RCRG is to assist in the review and evaluation of Research and Development Programs/Projects/Studies submitted to the Research and Extension Department both for local and foreign funding as well as assist in the evaluation of On- going Research and Development Programs/Projects/Studies both conducted in the College.

The RCRG is composed of academic Program Advisers and the Head of the Research and Extension Office of the College. For purposes of operationalizing its research agenda, the RCRG has to delve into the priorities in terms of commodities, that is, clustering the priority issues into groups under which research proposals are considered and classified. For this purpose, fields of specialization were devised such as Marine Fisheries, Aquaculture/Inland Fisheries, Processing Technology, Social $\mathrm{R}$ and D Priorities, and Education.

In the case of the WMSU, a separate department is created headed by the Vice President for Research and Development as the overall administrative officer of the university in all matters related to research and development. The Dean/ Director for Research heads the R \& D Department that supervises the actual flow of proposals as assisted by a Research Council Panel in reviewing proposals and the Technical Evaluation Group (TEG).

Research proposals undergo three (3) stages in proposal presentation to qualify for availment of institutional funding support. The stages include the Department Level, College/Unit Level, and the University Level. The application stage starts at the Department Level where the Department Chair with the assistance of the Department Research Committee endorses the proponent's research proposal to the Dean of the College.

With suggestions embodied in the proposal, the College Dean with the assistance of the College Head approves the proposal for inclusion in the Agency In-house Review of Proposals for funding by the university, CHED, DOST, DOH, or the proponent's funding agency. Upon passing the college/unit level, the proposal is scheduled to pass through the University Level where the Dean of Research transmits the proposal to the Technical Evaluation Group for evaluation whereupon 
suggestions and recommendations are considered. The Dean of Research schedules the proposal presentation before the Research Council Panel, which is tasked to evaluate the proposal before it is recommended for implementation.

For its part, the ZCSPC undergoes simple procedure in the conduct of research. In the College, there is created the position of the Dean of the Academic Support Group that is responsible for evaluating research proposals of teachers. For funding purposes, all research proposals have to pass through this office, which forwards the purposed to the Budget Officer for the release of approved funding support.

The ADZU adopts its own rules in proposal presentation. It starts with the submission of proposals by teachers and its referral to the Research Review Committee for its initial evaluation. The proposals are then returned to the proponents for improvement. After which, the proponents sign the Term of Reference or TOR. This is a research contract binding the teachers and the university. Data collection follows after the signing of the contract. Under specified time, the proponents submit the first draft of the research to the Ateneo Research Center or ARC. Thereafter, the proposal pre-presentation is scheduled before the Research Review Committee for revision of the draft report. After the approval with modification, the proponents present the research findings in a research utilization forum with stakeholders and later submit the final report to the ARC for publication.

The Universidad de Zamboanga defines its procedure in its Manual of Operation called the URC Manual of Regulations. For purposes of proposal submission, all proposals are classified either as self-funded, school-funded, or outsourced. All proposals are to be submitted to the University Research Center or URC for pre-evaluation before they are calendared. In the case of self-funded proposals, proponents have to present their proposals before the Research Panel, and thereafter proceed to data collection.

However, proposals that are school-funded in addition to presentation before the Research Panel are presented before the Research Council being the highest approving body of the university in all research-related matters. Proposals that are outsourced are simply evaluated by the URC without the need of presentation before the Research Panel or Council. However, these proposals have to be conferred with the funding agency concerned and culminate in the signing of memorandum of agreement.

In the case of the school-funded researches, all proponents have to be bound by a contract with the university. Research monitoring is done by the URC under a prescribed period as approved during the Council presentation except for the outsourced researches in which case stipulations of length of 
time and other pertinent provisions are governed by the terms of the MOA. All research outputs are presented in utilization forums as a requirement.

\section{3.. Faculty-researcher Benefits and Incentives}

The ZSCMST has provision for researcher's benefits or incentives that include de-loading of teaching hours with full pay as regular faculty members. These faculty researchers are only required to handle 9 to 12 hours of teaching per week. They are given incentives and honorarium, the amount of which depends on the amount of the research budget. The Project Leader receives Php 3,500.00, the Study Leader receives Php 3,000.00, and the Research Aid is paid on a salary basis.

In WMSU, incentives for research undertaking include de-loading, leave credit, term insurance ownership of patent, and the grant of finders' fee. Finders' fee is given to faculty researchers who draft research proposals for funding agencies. Depending on the amount of the grant, the researcher receives his fee on two installments, first after the draft of the proposal and second upon signing of the MOA. The faculty researchers are also entitled to receive the Best Paper Award and Special Award based on the quality of the research work. They are also entitled to receive all other existing university and national incentives such as hazard fees. The university adopts the de-loading system with the following equivalents: Program Leader for 9 teaching units, Project Leader for 6 units, Study Leader for 3 units, Research Chair/Coordinator/Head and R \& D Research Services Office for 3 units, Co-study Leader for 2 units, and College Research Committee Member for to 2 units.

The ZCSPC has a different policy in which only faculty members with the rank of Assistant Professor and higher are required to undertake research. However, they are still given the option to indulge in community extension service, production, or research. Experience shows that teachers prefer research to extension services and production. In any case, teachers are given incentives for doing research. Research undertaking is a plus factor in academic rank evaluation.

The ADZU adopts a de-loading system for faculty researches (6 units to full deloading) depending on the nature of the research. For those de-loaded, a favorable schedule of classes is arranged. A teacher-researcher enjoys his full salary released on schedule and a monthly stipend equivalent to $15 \%$ of the basic salary for 2 deloaded to be released upon completion of specific tasks like data gathering. An honorarium equivalent to three times the amount of the stipend is released upon submission of the final report. All teacher-researchers with completed researches are given recognition for research accomplishment that includes presentation of the results to the community, awarding of financial incentives, and possible publication of completed researches in Periodikit, Research Digest, ADZU Journal, 
Multidisciplinary Journal, and other publications released by the Ateneo Research Center. Likewise, research accomplishment is a key toward advancement in academic rank. Involvement in research works is crucial to qualify for associate professorship, achieve opportunity to harness research capability, and opportunity to present papers in national and international conferences.

The UZ adopts no subject de-loading as a matter of policy, but grants full deload to teachers depending on the nature and type of researches undertaken. For full de-load, the teacher-researchers are paid based on a fullload ( 24 units) salary. Teacher-researchers are given an approved budget for the research project, the amount of which depends on the scope and nature of the research. The budget is exclusively intended to finance the research projects and subject to the usual accounting requirement.

The budget is released on three installments of which $40 \%$ is released upon approval of the proposal, another $40 \%$ upon data collection, and the remaining $20 \%$ upon completion of the research project. An honorarium not less than Php 5,000.00 but not more than Php 25,000.00 is given for each completed research regardless of the number of researchers. The Research Council determines both the budget allocation and the amount of the honorarium. Proof of research work qualifies teachers to apply for re-classification of academic rank. The honorarium and budget for research proposals with outsourced funding is shouldered by the funding agency through contract stipulations.

\section{Research Publication}

Except for the ZCSPC, all schools in this study have their in-house official publication. All of the in-house researchjournals are non-refereed. The ZSCMST has two (2) releases of their school journal a year or one a semester. Although the ZSCMST has no refereed journal of its own, 9 of its research outputs were published in refereed journal from school year 2002-2007. The WMSU publishes its research journal once a year. The ADZU mainly has four different types of publication while the UZ has three.

All these journals print researches and scholarly works of their own faculty researchers. The distribution is uneven since there is no mutual understanding among HEIs to share their journal publication with one another on a regular basis. There is also no effort to jointly create a peer-reviewed journal. The recipients or end users of the journals depend upon the determination and choice of the school for which copies are distributed. School journals vary in the number of articles they print, ranging between 7 to 10 articles per publication.

There is also, a low turnout in the number of researchers who sent their research articles to international refereed journals. This is so because of the 
small number of completed researches per year, low acceptance rate imposed by sponsor-institutions, and the lack of exposures of researchers in publishing their research works in venues other than their own school journals, among others. The schools have not yet used their websites as medium for their research publication.

\section{5.. Linkage and Networking}

Only two universities have the long list of research partnerships. The WMSU has partnership with Manos Unidos in Spain, Asia Pacific Policy Center or APPC, Center for the Welfare of Children or CWC, DOH, DOST, TESDA, POPCOM, PCARRD, Volkwagen Foundation, DAR Basilan, and the local government of Zamboanga del Sur, Zamboanga del Norte, Zamboanga City, the Province of Sulu, and Tawi-Tawi. WMSU has also established networking with UP Pahinungod and John Hopkins University.

The ADZU for its part has maintained partnership with several institutions such as the Australian Agency for International Development or AusAID, the World Bank, Asian Institute of Management (AIM) Policy Center, Multi-faith Center in Griffith University, Australia, International Christian University in Tokyo, United Nations Educational, Scientific and Cultural Organization or UNESCO, United States Agency for International Development or USAID, The Asia Foundation or TAF, Philippine Council for Health Research and Development or PCHRD, Tabang Mindanao/Assisi Development Foundation or ADF, Nagdilaab Foundation, Inc. or NFI, Notre Dame University or NDU, Notre Dame of Jolo College or NDJC, Silsilah Dialogue Movement, Catholic Relief Service or CRS, and the Notre Dame Foundation for Charitable Activities-Women in Enterprise Development or NDFCAI-WED, among others.

The other school with limited networking and linkages include the Universidad de Zamboanga and ZSCMST. Because of its late inception in 2004 as a Research Center, the Universidad de Zamboanga has established partnership with few organizations like the Philippine Society for Educational Research and Evaluation or PSERE based in Centro Escolar University, Manila. It has spearheaded the organization of the Zamboanga Peninsula Research Society or ZPRS in Region IX.

The URC is a member/officer of the newly organized Philippine Association of Institutions in Research or PAIR based in Liceo de Cagayan University. It has established partnership with the local governments of Isabela and Zamboanga City. Likewise, it has established partnership with Liceo de Cagayan University, The Asia Foundation or TAF, Global Development Network or GDN, the Nippon Foundation, and Luma Ma Dilaut, among others. 
Liceo Journal of Higher Education Research

The ZSCMST has research networking with the Bureau of Agriculture and Research or BAR, PCAMARD, DOST, BFAR, Growth Equity for Mindanao or GEM, and the local government of Zamboanga City. The ZCSPC had acknowledged networking partnership with the Asian Development Bank or ADB for funding of its research.

\section{6.. Research Utilization Forum}

The conduct of research utilization forums is very much dependent on the availability of completed researches. As such, all except the WMSU are flexible in scheduling of their research utilization forums. The WMSU has a regular schedule of research presentation as stipulated in its Manual of Regulations. Most recently, WMSU held a two-day forum in May where 24 researches were presented.

\section{Plans for Improved Teacher Participation in Research}

Capability building and improved incentives for researchers are common strategies among HEIs in their attempt to generate more teacher participation in research undertaking. Each institution, however, has its own plans and specific attention as to the nature of training and incentives. In all cases, teacher participation in research may be considered minimal in relation to the total number of teachers per institution.

The ZSCMST looks at capability building and immersion as two important plans for improved participation. The plan is designed to direct attention to marine science researches. Immersion, for instance, is necessary for actual experience in hatchery sites such as in Iloilo and the presence of research station in Cebu.

The WMSU has a Ten-Year R \& D Plan for 2005-2014. The Plan serves as basis for all development policies of the Office including upgrading of the office equipment as well as the grant of incentives and awards to the researchers. The ZCSPC undertakes capability building for its faculty members; however, the college administration admits that despite the grant of incentives, it is difficult to get faculty to do research.

The ADZU undertakes capability building among its faculty to strengthen the culture of research. It supports its faculty researchers in the conduct of their own choice of research by providing materials, equipment, and manpower as well as training in terms of seminars and workshops.

The Universidad de Zamboanga's plans are contained in its Research Action Program for 2005-2010. The Program is mainly divided into three parts: Research and Publication, Dissemination and Publication, and Linkaging and Networking, each with specific objectives, strategies, key indicators and resource-designate. Among its most common programs are capability building and strengthening the culture of research among its faculty members. 


\section{Current Obstacles Experienced by Researchers}

The difficulty in doing research among the faculty may be categorized in terms of the three main areas of the research cycle: Research and Publication, Research Dissemination and Utilization, and Research Linkaging and Networking.

\section{Research and Publication}

Firstly, teachers found it difficult to undertake research due to their regular teaching loads (between 21-24 units regular/full-time teaching). Although, there is some kind of de-loading system among most institutions, there is not enough time to faithfully do research in its genuine sense. A de-loading of 3 or 6 units may not allow teacher researchers to proceed to research sites outside the school campus since they worry about their teaching time immediately thereafter. Some teacher researchers undertook research for the love of it while still others did research for academic compliance with accreditation or evaluation.

Secondly, most teachers did not have the readiness to undertake research work due to their insufficient formal training in research. The inculcation of research in undergraduate curriculum came about lately. Teachers had research training in the graduate school while others simply possessed personal skills in doing research. Some teachers lacked the experience and exposure to research since they simply concentrated on their teaching function. Research seminars and workshops were occasionally held within the locality. Research culture among most colleges and universities in the city has yet to be developed. Teaching or classroom instruction is believed to be the main task of a college faculty. The relation of research to instruction has not been fully understood. In fact, research is prioritized for accreditation and evaluation purposes rather than for actual generation of empirical knowledge for academic use.

Thirdly, the lack of financial and logistics, support from the administration was believed to be an obstacle in research. It has become a policy this time that research is a criterion for academic ranking and in some cases sine quo non for evaluation. Nonetheless, the financial assistance given was not viewed as remunerative enough. Hence, research undertaking from the point of view of the faculty was unattractive. Full-time teaching was, in fact, preferred to doing research works with subject de-loading. Some schools lacked the facilities and for research equipment. Government schools have to go the process of bidding as required by law, causing delay in the procurement of necessary technology. Fetalver's (2003) cited that the system of research funding, availability of research facilities and research journals and publications, and availability of library facilities, holdings and materials were areas that urgently needed improvement in an attempt to improve research productivity. 
Lastly, most teacher-researchers did not have access or exposure to funding agencies for some obvious reasons- lack of tract record and linkaging. As such, researchers undertook researches within the bounds of the allotted school budget or financed their own researches for topics that were not institutionally endorsed and funded.

The low turnout of teacher researchers relatively affected research publication. As a rule, publication follows the quantity and quality of research outputs. Most completed researches of schools in the locality are printed in in-house journals. While all these journals are ISSN registered, they were not posted in the school websites for wider dissemination. As such, research outputs lose the opportunity to be quoted as literature by other researchers dealing with similar studies. In other words, their dissemination goes as far as their circulation or distribution goes. All HEIs in the city did not have their refereed journal. Only few of their researches were published in external refereed journals.

\section{Research Dissemination and Utilization}

Except for ZCSPC, all others have their medium of dissemination of research findings. Dissemination of research findings is limited to their own publication. Utilization forums were conducted only when there were completed researches. Most schools did not have regular presentation of findings. Utilization forums were used to showcase findings more for presentation's sake than for actual utilization- where stakeholders are present to analyze how the findings can be applied to their respective fields. Only researches that were funded by funding agencies were taken for utilization. Generally, few researches of these institutions were approved for presentation in national and international forums.

\section{Research Linkaging and Networking}

All institutions have their respective linkages and networking with other research institutions outside the city and abroad. However, these schools lacked research networking with one another. Among them, no collaborative research works has beenconducted. In the case of external linkaging and networking, some HEIs availed of some fundings for some of their researches though some linkaging and networking did not necessarily entail funding support. Linkaging and networking provide access for wider cooperation in research-related activities in terms of undertaking, publication, and funding.

Generally, HEIs had difficulty generating funding support because of the lack of tract record in research and exposure of their researchers. While there are regional, national and international research bodies with which cooperation may be sought, HEIs, however, secured membership only with few research societies. 
Of these research societies, only one of them is based in the city. The Zamboanga Peninsula Research Society or ZPRS is spearheaded by the Universidad de Zamboanga and was organized through and in consultation with the Commission on Higher Education in Region IX and participated in by HEIs in the region. The ZPRS is the only organized research society in the Zamboanga Peninsula for now.

Ongoing Programs in Research

In the case of the ZSCMST, its institutional priority lies in its efforts to instill capability building and immersion among its faculty members. It is intended to give teacher-researchers an actual experience by having exposures to sites that are relevant in the nature of their future researches being a marine science institution. Capability building is likewise the overall priority of the ZCSPC. Despite this effort, it was revealed that only a handful of teachers engage in research work. The difficulty is partly curved by the allocation of budget for research.

The WMSU has defined its priority programs in its Ten-Year R \& D for 20052014 that includes upgrading of its facilities in research. The university is working on to improve its incentives, reward, and award system to generate more teacher participation. For its part, ADZU continues to follow its approved programs to get more faculty members into research. One program is the provision of material support, equipment, and manpower training as well as continuous reward system.

The UZ also continues its capability building as one mode of establishing the culture of research among its faculty. Continuous training and improvement in reward system and detailing qualified faculty members in URC with full deloading are among the latest trends to attract teachers to do research work. Overall, capability building has been considered as the priority effort by all institutions in the attempt to generate more teacher participation in research. It confirms the earlier finding that teachers are yet in the process of appreciating research as part of their functions in higher education institution. Of course, other mechanisms are in place to assist teacher-researchers in this effort, which vary from one institution to the other.

\section{CONCLUSIONS}

The public and private HEIs have relatively low average percentages of teachers with research works over the five-year period. An average of $2.5 \%$ of the teachers in the public schools in the five-year period did research works while only $2.0 \%$ did in the private schools. Analyzed in terms of school status, universities only have an average $2.9 \%$ faculty researches in the five-year period while the 
colleges have $4.3 \%$. These percentages must not be confused with actual number of teachers performing research works because as stated elsewhere, the universities showed higher teacher percentage performing research works and showed greater quantity of research outputs than the colleges.

Public HEIs do not significantly differ from private HEIs in terms of the number of researches undertaken by each faculty-researcher, although the former showed more research outputs than the latter. This is so because one (1) public HEI does not have extensive research outputs, which as a group affected the research outputs of the entire public HEIs in the city causing their research outputs to be statistically similar to those of the private HEIs. However, in terms of school status, the research outputs of the universities undertaken by each of their facultyresearchers significantly differ from those of the colleges because the universities combined have higher research outputs since only one of the colleges is researchperforming.

The number of researchers involved per research in the public HEIs is statistically similar with those in the private HEIs. This is parallel to the above finding since in terms of type of school, public and private HEIs are similar in their quantity of research outputs as in the number of faculty involved in research. But again, the case is different when HEIs are compared according to status because universities show greater number of teacher participation in research than the colleges. Aside from the reason cited in earlier conclusion, there are only two colleges in the city with evidence of research work. Despite the differences in the number of research outputs and the number of researchers per research work between private and public HEIs and between the colleges and universities, the statistics of faculty members (including researchers of RCs) who undertook research works were basically similar.

In terms of the nature of research, institutional researches characterized most of the researches of HEIs in Zamboanga City. In part, this may mean that schools take institutional researches as a priority over other researches. This being the case, other kinds of researches may have not yet been explored for reasons that HEIs either lack expertise in other fields of research or lack the need for them at the onset. By implication too, this may mean limited research utilization as well as exposure to regional, national, and international presentations of research outputs. While mostly being institutional, most of these researches are simply descriptive in type. Few are experimental and historical. Institutional descriptive researches abound across type and status of school.

Since many researches are school-funded, expectedly most research outputs are published in in-house journals. For this reason, most research outputs are locally disseminated as well as utilized. International refereed journals impose very low 
acceptance percentage and are not readily available to HEIs in the city. HEIs have to create their own peer review system to gain access to refereed publication. No HEIs, however, showed proof of in-house refereed publication system.

Each HEI enjoys full autonomy in devising its own research vision, mission, and agenda. For this reason, research agenda of each school reflect the priority and academic discipline that characterized each institution. Technical HEIs have more specialized research agenda than do the multi-disciplinary schools. All HEIs regardless of type and status follow a prescribed and approved research procedure, but financial allocations for research proposal proved to be quite difficult among the public HEIs. In terms of benefits and incentives for researchers, most HEIs provide incentives and benefits to chairmanship in research that include budget for the research, honorarium, de-loading of academic or teaching loads, guarantee in research presentation, copyright, and material or office equipment assistance.

The current obstacles of all the HEIs can be classified into three (3) categories: Research and Publication, Research Dissemination and Utilization, and Research Linkaging and Networking. These areas are found to be interrelated and development in one has consequential effect on the others. The low participation of teachers in research and the eventual low research outputs are concerns of all the HEIs. They attribute this condition to teachers' academic loading and less attractive package of incentives, among others. This in effect negatively affects dissemination and utilization since most HEIs' researches are institutional, thus may impact the possibility of schools getting funding from outside sources. Therefore, all HEIs must take these three areas into consideration when coming up with innovative measures.

\section{LITERATURE CITED}

Cross, K.P (2000). The educational role of researchers. In A. Kezar \& P. Eckel (eds.), Moving beyond the gap between research and practice in higher education. San Francisco: Jossey-Bass.

Fetalver, M. Jr. A. (2003). Research culture in state higher education institutions (SHEIs) in Region IV: proposed research program for institutional research development. Dissertation , (Ph D) University of Santo Tomas. Manila, Philippines.

Fuhrman, S.H. (1992). "Uniting producers and consumers: challenges in creating and utilizing educational research and development." Washington, DC: Paper presented at the International Seminar on Educational Research and Development.

Huberman, M. (1992). "Linking the practitioner and researcher communities 
for school improvement." Victoria, British Columbia: Keynote Address, International Congress for School Effectiveness and Improvement.

Huberman, M. (1995). "What knowledge is of most worth to teachers? a knowledge-use perspective." Teaching \& Teacher Education, 1 (3), 252-262.

Turnbull, B. J. (1992) "Research knowledge and school improvement: c an this marriage be saved?" San Francisco: Paper presented at Annual Meeting of the American Educational Research Association.

Weiss, C. (1999) "Congressional committees as users of analysis. Journal of Policy Analysis and Management., 8(3) 411-431. 